\title{
The effect of psycho-education about maternal attitudes on childhood obsessive compulsive disorder symptoms
}

\author{
Anne tutumlarına yönelik psikoeğitimin çocukluk çă̆ı obsesif kompulsif \\ bozukluk semptomlarına etkisi
}

Ecem Akıncı' ${ }^{1}$ Oya Mortan Sevi²

${ }^{1}$ Clin. Psych., Marmara Education Institutions, Kocaeli, Turkey, https://orcid.org/0000-0001-7983-1656

${ }^{2}$ Assis. Prof., Bahcesehir University, Faculty of Economics, Administrative and Social Sciences, Department of Psychology, Istanbul, Turkey https://orcid.org/0000-0002-2962-8286

\section{SUMMARY}

Objective: The primary goal of the present study is to investigate relationship between maternal attitudes and subclinical childhood Obsessive Compulsive Disorder (OCD) in Turkish sample. Study also investigates the effectiveness of 8-sessions psycho-education program about maternal attitudes. Method: Sample consisted of 97 mother-child pairs and children's age ranged between 8 to 10. Parental Attitudes Research Instrument (PARI), Leyton Obsessional Inventory Child Version (LOI-CV), State-Trait Anxiety Inventory for Children (STAI-CH) and Children's Depression Inventory (CDI) were used as assessment tools. After initial assessments, fifteen mothers randomly assigned either to group psycho-education condition $(n=8)$ or waiting-list control condition $(n=7)$. Results: Marital conflict was positively correlated with total interference score in LOI-CV, total score in LOI$\mathrm{CV}$ and A-Trait anxiety symptoms $(r=.23, r=.24$ and $r$ $=.24$, respectively). Authoritarianism positively correlated with A-Trait anxiety symptoms $(r=.25)$. Findings also indicated that there was a statistically significant difference in total scores of negative attitudes $(Z=-2.201$, $\mathrm{p}=.028$ ), and posttest scores of these variables showed significant decrease after psycho-education program. There were statistically significant change in interfere $(\mathrm{Z}=-2.371, \mathrm{p}=.018)$ and total $(\mathrm{Z}=-2.366, \mathrm{p}=.018)$ score of OCD symptoms after psycho-education program. Discussion: Marital conflict has a significant relationship with subclinical OCD symptoms. Marital conflict and authoritarian attitude also have significant relationship with trait anxiety symptoms in children. Furthermore, psycho-education program was effective in reducing negative maternal attitudes and children's subclinical OCD symptoms

Key Words: Childhood obsessive-compulsive disorder, parental attitudes, psycho-education, effectiveness

\section{ÖZET}

Amaç: Çalışmanın öncelikli amacı Türk popülasyonunda anne tutumları ve çocukluk çağı eşik altı OKB belirtileri arasındaki ilişkiyi incelemektir. Çalışmada, anne tutumları ile ilgili 8 seanslık psiko-eğitim çalışmasının etkililiğinin de incelenmesi amaçlamıştır. Yöntem: Örneklem, 8-10 yaş grubu çocuklar ve onların anneleri olmak üzere 97 çocuk-anne çiftinden oluşmuştur. Aile Hayatı Çocuk Yetiştirme Tutum Ölçeği, Leyton Obsesyon EnvanteriÇocuk Formu, Durumluk/Sürekli Kaygı Envanteri-Çocuk Formu ve Çocuklar için Depresyon Ölçeği ölçüm araçları olarak kullanılmıştır. Illk ölçümlerin ardından, 15 anne seçkisiz atama yöntemi ile psiko-eğitim $(n=8)$ ve bekleme listesi-kontrol gruplarına $(n=7)$ atanmıştır. Bulgular: Evlilik çatışması ve OKB semptomlarının şiddeti, OKB semptomları, ve sürekli kaygı semptomları, arasında pozitif yönde anlamlı ilişki saptanmıştır (sırasıyla, $r=.23, r=.24$ ve $r=.24$ ). Otoriter tutum ise sürekli kaygı belirtileri ile pozitif yönde anlamlı biçimde ilişkilidir $(r=.25)$. Bulgular ayrıca, annelerin negatif tutumlarında $(Z=-2.201, p=.028)$ istatistiksel olarak anlamlı değişim görüldüğünü ve son test ölçümlerinde anlamlı düzeyde azalmanın olduğunu göstermektedir. Psiko-eğitim sonrası OKB semptomları $(Z=-2.366$, $p=.018)$ ve semptomların şiddetinde $(Z=-2.371$, $p=.018)$ anlamlı değişim saptanmıştır. Sonuç: Evlilik çatışması, eşik altı OKB semptomlarıyla anlamlı derecede ilişkilidir. Evlilik çatışması ve otoriter tutum, sürekli kaygı belirtileriyle anlamlı derecede ilişkilidir. 8 haftalık psikoeğitim programının hem annelerin olumsuz tutumlarını hem de çocuklarda görülen eşik altı OKB semptomlarını azaltıcı etki gösterdiğini saptanmıştır.

Anahtar Sözcükler: Çocukluk çağı obsesif kompulsif bozukluğu, ebeveyn tutumları, psikoeğitim, etkililik

(Turkish J Clinical Psychiatry 2020;23:7-22)

DOI: $10.5505 / \mathrm{kpd} .2020 .82612$ 


\section{INTRODUCTION}

\section{The Features and Etiology of Childhood Obsessive Compulsive Symptoms}

Childhood Obsessive Compulsive Disorder (OCD) is characterized by intrusive, recurrent and inappropriate thoughts, impulses and images that cause anxiety and marked distress, which are identified as Obsessions. Furthermore, it includes repetitive behaviors (e.g. hand washing, ordering) and mental acts (e.g. counting, repeating words), which are aimed at reducing distress and preventing anxiety, that are identified as Compulsions. As seen in adults, these obsessions and compulsions produce distress, are time-consuming, and may cause severe impairment in one's social, emotional and educational life (1). Subclinical OCD defines a widely seen condition in both nonclinical children and adult population, in which obsessive-compulsive symptoms still exist as found in clinical OCD. Nevertheless, there is no severe functional impairments in lifestyle (2). Likewise, in subclinical OCD, obsessive-compulsive symptoms are not severe enough to diagnose full-blown OCD (3).

Previous research has demonstrated that the prevalence of subclinical OCD in children ranged between nineteen percent and twenty-seven percent $(4,5)$. These findings reveal the importance of investigating links between subclinical OCD and clinical OCD. However, the relationship between subclinical OCD and clinical OCD is still controversial. Subclinical OCD can be precursor of OCD or it can be also a part of OCD spectrum, which does not necessarily indicate a progression to $\mathrm{OCD}$ (5).

Although previous studies focused on the development of childhood OCD and found that it is a neurobiological disorder, recent studies have begun to focus on the maintenance factors of OCD. Particularly in childhood OCD, familial factors stand out as a maintenance factor. As discussed in previous studies, family interaction, accommodation and family involvement in OCD symptoms are significant factors for the maintenance of OCD in children $(6,7,8)$. Negative attitudes (criticism, overinvolvement, doubt, hostility etc.) of parents and parental rearing styles also have a role in childhood OCD. In particular, family interaction is considered as a one of the risk factors in development and maintenance of childhood OCD. Therefore, researchers have focused their investigations on the link between childhood OCD, expressed emotion and parental rearing styles. Results indicated that parent and child behaviors during family interactions differ in families who have child with and without OCD. Children with OCD were less warm, have less positive problem solving skills and are less confident. Parents of child with OCD showed less permission for autonomy and were less confidence in their child's ability (9). A previous study also found that there are increased levels of criticism, hostility and/or emotional over involvement, which are defined as expressed emotion within families of children with OCD (10). In parallel with other studies, one study found a link between increased rejection/criticism and child's compulsions (11). They predicted that this link could be a reaction of the child to punishing negative attitudes of family members or these negative attitudes (rejection and criticism) can cause an increase in the child's anxiety and this leads more compulsions. Researchers also placed emphasis on the relationship between parents. Marital conflict defined incoherency, inconsistency and instability between spouses. The contribution of marital conflict on childhood anxiety disorders was explained (12) and it was found that parents' inconsistent and instable attitudes lead to the experience of uncontrollability and insecurity in children, which results in anxiety. Marital conflict is a one of the factors that exacerbate the course of OCD, and also threaten the treatment process (13). Disagreement about the disorder can cause distress in children and that also affects the development and maintenance of OCD symptoms.

\section{Psychological Treatments for OCD Symptoms}

Before planning a treatment, a detailed assessment of the child in conjunction parents and schoolteachers is essential. Childhood OCD demonstrates differentiation depending on the individual case. The course of childhood OCD can be affected by several factors (comorbid disorders, developmental level of child, familial context or other psychosocial factors), and consequently all of this information must obtained as part of the 
assessments. Because the development of OCD differentiates from person-to-person, treatment plans for OCD are organized in a more individualistic way. In general, the treatment of OCD includes pharmacotherapy, cognitive behavioral psychotherapy (CBT) and combined therapies.

CBT is a prominent therapy, which shows effective results in the treatment of children with OCD. However, results have indicated that family-related issues are an important factor associated with poor outcomes of CBT in childhood OCD treatment.

Furthermore, rather than family involvement, parent-only interventions have become a treatment option in recent years. A study was conducted with families of children with OCD who also refused individual CBT (14). A manualized parent-only intervention was applied to parents across ten sessions. In conclusion, parents reported a significant reduction in the OCD symptoms of their children. More recently, the effectiveness of parent-only intervention of OCD compared to cognitive behavioral family-based treatment (CBFT) was also assessed (15). Results showed that both the parent training interventions and CBFT interventions produced positive treatment outcomes. Moreover, in both situations, family accommodation, internalizing and externalizing problems significantly reduced. However, both family-involved treatment processes and parent-only interventions do not directly contain any strategies for changing negative parental attitudes.

\section{Psycho-Education about Parental Attitudes for Childhood OCD}

Psycho-education can be described as "a process that is crucial for all treatments in which knowledge about the relevant disorder is provided to clients" (16). In general, psycho-education was used as an educating program for the child and family about the disorder. It provides knowledge to the child and family about OCD symptoms, how the disorder is developed and maintained and contains information about treatment options. In more comprehensive studies, psycho-education can be also used as a guide for families to cope with their child's symptoms and behaviors and to teach the family how to cope with the child's rituals. In one study, a psychosocial comparison condition was used in addition to family based CBT and a psychoeducation/relaxation-training program was applied to some of the participants and their families (17). Even though the particular content of psycho-education shows similarity with classical studies, results indicated that the psycho-education/relaxation training program can lead to a reduction in familyreported psychosocial impairments.

Even though the maintenance effect of parental attitudes on childhood OCD is well known, there is still a significant gap in the literature about specific intervention studies that focus on parental attitudes. The rarity of studies examine the effect of psycho-education in the literature (18). These studies also suggested that psycho-educational programs have to focus on knowledge about OCD, accommodation behaviours and negative parental attitudes (19). Nevertheless, it can be seen that a significant aspect of these studies did not consider psycho-education programs focusing on the families' own attitudes. Furthermore, it is still unclear which family related factors led to changes in child symptomatology.

\section{The Aim of This Study}

Due to the gap in Turkish literature, the first aim of this study is to investigate the relationship between maternal attitudes and subclinical childhood OCD symptoms. Furthermore, the second and main aim of the study is to examine the effect of a psychoeducation program about maternal attitudes on childhood OCD within the context of a Turkish sample. To achieve this main study aim, the authors developed a structured and manualized psychoeducation program based on previous parent only interventions. The psycho-education program aimed to produce significant reductions in negative parental attitudes and significant reductions in child's subclinical obsessive-compulsive symptoms. The effect of specific psycho-education on parental attitudes to subclinical childhood OCD symptomatology was examined for the first time with this psycho-education program. 


\section{METHOD}

\section{Participants}

\section{Participants of pre-assessment phase}

The participants in this study comprised third and fourth grade students and their mothers, who were selected from two government schools in Kocaeli. Consent forms were sent to families via the third and fourth grade students in these schools. Based on mothers' approval, ninety-seven child mother pairs were included to study. Children with known a diagnosis of major depressive disorder, early onset psychosis or bipolar disorder, cognitive, neurologic or physical deficit were excluded. Mothers' assessment instruments consisted of a demographic questionnaire and The Parental Attitude Research Instrument (PARI). The Leyton Obsessional Inventory Child Version (LOI-CV), State-Trait Anxiety Inventory for Children (STAI-CH) and Children's Depression Inventory (CDI) were used as assessment tools for children.

\section{Participants of psycho-education phase}

Twenty-nine children scored above the mean scores in Leyton Obsessional Inventory Child Version (LOI-CV) and State-Trait Anxiety Inventory for Children (STAI-CH), and their mothers achieved high scores from at least one of the subscales of Parental Attitudes Research Instrument (PARI), which indicated negative parental attitudes. Consequently, these twenty-nine mothers were selected for the effectiveness study of psycho-education. Fifteen of them approved to participate ingroup sessions. These mothers were randomly assigned to either the psycho-education group or the waiting list control condition group (see procedures below more details). At the start of the psycho-education group sessions, one mother chose not to continue with the program.

\section{Measurements}

PARI: The shortened version of PARI was used in this study and includes 60 items rated on a 4-point Likert scale. The instrument has 5 sub-scales, which are: 1- dependency, 2-egalitarianism and democratic attitude, 3- rejection of the homemaking role, 4- marital conflict and 5- authoritarianism. The shortened version of PARI was firstly adapted to Turkish by LeCompte and colleagues (20). Testretest reliability of the factors was found between .58 and .88 for Turkish version. Küçük has performed the second adaptation of PARI (21). In the current study, the alpha coefficient of the egalitarianism and democratic attitude subscale was found to be .28 , which indicated an unacceptable value whereas alpha coefficients of other subscales were between .74 and .81 that indicated acceptable values.

LOI-CV: Short form of LOI-CV was used in this study and consisted of 20 items. Each of the 20 items includes two responses: the presence/absence of the symptom described in the item (yes/ no) and the interference of the symptom if it is present: from 0 (no interference) to 3 (high interference). If a child chooses the "yes" option he/she is then required to rate the interference of the item on a 4point Likert scale. The cut-off points for evaluating LOI-CV are 15 for the yes scores, 25 for the interference score, with 35 for the total score. Higher scores indicate a greater level of interference. The Turkish version of the LOI-CV was developed by Palulu and Erol (22). The Turkish version of the inventory consists of four factors: 1 - cleanliness and tidiness, 2- repetition and indecision, 3- special words and numbers and 4- checking. In this study, LOI was used to identify subclinical obsessive-compulsive symptoms and the alpha coefficient of the total score was found to be .89 .

STAI-CH: The STAI-CH assessment consists of two separate, self-reporting scales and each section consists of 20 statements. Participants are required to rate on a 3 point scale ranging from hardly ever to often. For both sections, the total score range is from 20 to 80 , with higher scores indicating a greater level of anxiety. The Turkish version of STAI-CH was established with Cronbach's alpha coefficient .82 , and .81 respectively for A-State and A-Trait scales (23). In current study, the alpha coefficients of the A-State and A-Trait were found to be .87 and .84 , respectively. 
CDI: The CDI consists of 27 items and each item is given a score between 0 and 2 . Total scores ranged from 0 to 54 and cut off point is proposed as 19 . Higher scores indicate a greater level of depression. The original version of CDI has demonstrated relatively high levels of internal consistency, with a coefficient alpha of 86 (24). The Turkish version of the CDI has a good concurrent validity and reliability with Cronbach's alpha .77. In current study, the alpha coefficient of the scale was found to be .80 .

\section{Procedure}

Firstly, an approval for this study was obtained from Bahçeşehir University Committee for Research and Publishing. Then, permission of Kocaeli City National Education Directorate was received for the data collection and application of the study in an educational environment. The study involved three phases: pre-assessment phase, psycho-education phase and post-assessment phase.

\section{Pre-assessment phase}

Initially, school administrations and related teachers were informed about study. A prepared information form, consent form, demographic questionnaire and PARI packs were distributed to children with the help of teachers. Children were asked to take the information form, consent forms, demographic forms and PARI home and for the documentation to be completed by the mothers. The information forms informed mothers about the study aims and the intention to examine specific anxiety symptoms in children and maternal attitudes. It was requested that mothers give their contact details in consent forms in order for further communication about psycho-education to occur. Because personal information was requested, confidentiality issues were discussed in the information forms. Mothers willing to participate were asked to return the signed consent forms with completed demographic questionnaires and PARI to the school. As a result, ninety-seven mothers agreed to participate in the study and completed PARI. Based on the mothers' consents, their children were also assessed through LOI, STAI and CDI. Children were told that they are randomly determined for taking part in a study that tried to exam- ine emotions and behaviors of children and mothers. They were also reminded that it was not a test and there were no correct answers.

From these ninety-seven participants, twenty-nine of children scored above the mean scores in LOI and STAI and, at the same time, their mothers also had high scores from at least one of the subscales of PARI which indicated negative parental attitudes and consequently this group were determined as the participants of the psycho-education phase.

\section{Psycho-education phase}

As a result of the findings obtained from the preassessment phase, twenty-nine mothers were invited to participate in the psycho-education program via telephone calls from a researcher. Information about findings and psycho-education sessions was given to mothers via these telephone calls. Additionally, the reason that they were chosen for this program was briefly explained them. Following these conversations, from the original twenty-nine mothers, fifteen of them agreed to participate in the psycho-education groups. For comparison purposes, these mothers were randomly assigned to either group psycho-education or waiting list control condition. Finally, researchers made contact with the eight mothers assigned to the group psycho-education condition, and an agreement was made regarding days and times of the psycho-education sessions. The waiting-list control condition group also were informed about the process and date the psycho-education sessions would begin.

The psycho-education program was developed based on a literature review on problems experienced by the parents of children with OCD and other anxiety disorders. Within this framework, the psycho-education program consisted of eight sessions which included information about nature of OCD, its development and maintenance in children, prevalent negative parental attitudes, functional parental attitudes, emotional self-awareness, thought-emotion-behavior relationship, managing stressful situations, coping techniques and effective communication skills. For each topic, a presentation was prepared. Presentations were supported by videos, exercises and role-plays. A booklet was 
also given to mothers and weekly homework was assigned within the booklets.

For the psycho-education program, all mothers in both schools were invited to meet in one of the schools. Program was arranged as a weekly $90 \mathrm{~min}-$ utes group session for each week held in the conference hall of a selected school. All detailed information relevant to psycho-education program is presented in Table 1.

\section{Post-assessment phase}

The 8th session of the psycho-education program was planned as a post assessment session for mothers. In this fnal session, mothers were requested to complete PARI again. Simultaneously, LOI and STAI were applied to the children again. This completed the post-assessment phase for both mother and children.

For comparison, mothers and children in the waiting-list control group repeated the LOI, STAI and PARI.

\section{Data Analysis}

Prior to analysis, the subscales of PARI, which are dependency, egalitarianism and democratic attitude, rejection of the homemaking role, marital conflict and authoritarianism, the subscales of LOI which are general obsessive, dirt-contamination, numbers-luck and school, A-State and A-Trait, and child depression symptoms were examined through IBM SPSS program for accuracy of data entry, missing values, fit between their distributions and the assumptions of multivariate analysis.

All missing values were replaced by the mean. No univariate outliers detected. By using Mahalonobis distance with $\mathrm{p}<.01$, derived from leverage scores, 8 multivariate cases were identified as multivariate outliers. 8 multivariate outliers were deleted, leaving 97 cases for analysis.

\section{RESULTS}

\section{Descriptive Statistic}

\section{Descriptive statistics of pre-assessment phase}

The age of the children ranged between 8 and 10 $(\mathrm{M}=8.88, \mathrm{SD}=.68) .57(58.8 \%)$ of the children were girls, $40(41.2 \%)$ of them were boys. 49

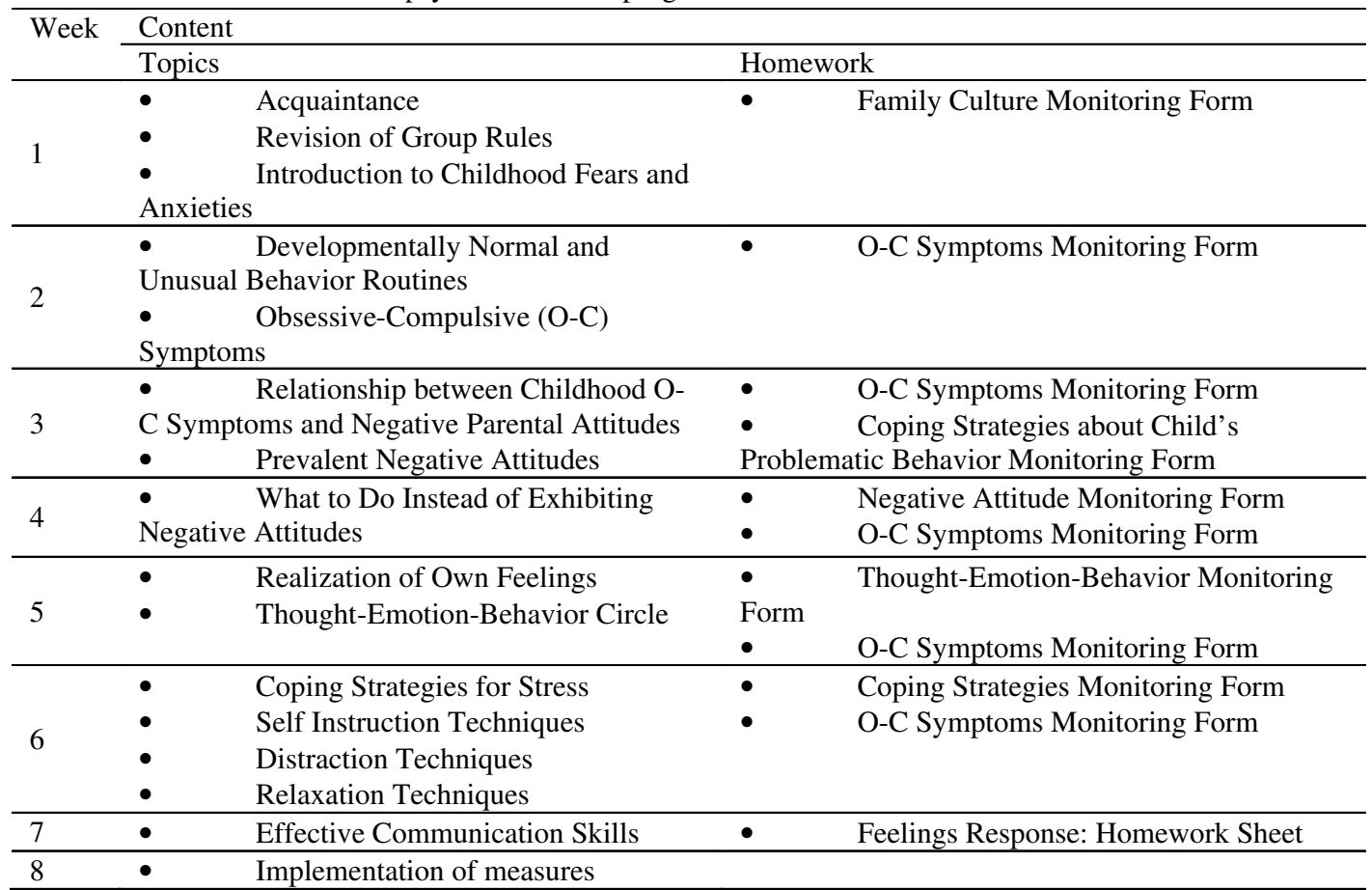


Table 2. Socio-demographic characteristics of children in pre-assessment phase

\begin{tabular}{lll}
\hline Variables & $\mathrm{N}$ & $\%$ \\
\hline Gender & & \\
\hline Girl & 57 & 58,8 \\
\hline Boy & 40 & 41,2 \\
\hline Grade & & \\
\hline $3^{\text {th }}$ grade & 49 & 50,5 \\
\hline $4^{\text {th }}$ grade & 48 & 49,5 \\
\hline
\end{tabular}

$(50.5 \%)$ of children attended 3rd grade at school and $48(49.5 \%)$ of them attended 4 th grade. The age of the mothers ranged from 27 to $48(\mathrm{M}=$ $35,41, \mathrm{SD}=4,92)$. Their education levels varied from primary school to university. 28 of mothers $(28.9 \%)$ graduated from primary school, 19 of them $(19.6 \%)$ graduated from secondary school, 33 of them $(34 \%)$ graduated from high school, 6 of them $(6.2 \%)$ graduated from college and 11 $(11.2 \%)$ of them graduated from university. While looking at the mothers' current working status, 26 $(26.8 \%)$ of them are working in a job whereas 71 $(73.2 \%)$ of them are not working. When considering marital status, $93(95.9 \%)$ of the mothers are married whereas $4(4.1 \%)$ of them are divorced. None of the mothers received any psychological interventions and none of them used psychiatric drugs during the process.

All detailed information relevant to socio-demographic characteristics of children and mothers in pre-assessment phase is presented in Table 2 and 3 .

\section{Descriptive statistics of psycho-education phase}

In psycho-education group, $2(28.6 \%)$ of the children were aged at 8, $3(42.9 \%)$ of them were 9 and $2(28.6 \%)$ of them were $10.4(57.1 \%)$ of the children were girls, $3(42.9 \%)$ of them were boys. 2 $(28.6 \%)$ of children attended 3 rd grade at school and $5(71.4 \%)$ of them attended 4 th grade. In waiting list control group, $2(28.6 \%)$ of the children were aged at $8,2(28.6 \%)$ of them were 9 and 3 $(42.9 \%)$ of them were $10.4(57.1 \%)$ of the children were girls, 3 (42.9\%) of them were boys. 4 (57.1\%) of children attended 3rd grade at school and 3 $(42.9 \%)$ of them attended 4 th grade.

In psycho-education group, $2(28.6 \%)$ of the mothers were below the age of $30,3(42.9 \%)$ of them were aged between $30-40$ and $2(28.6 \%)$ of them were above the age of $40.2(28.6 \%)$ of mothers graduated from primary school, $1(14.3 \%)$ of them graduated from secondary school, $4(57.1 \%)$ of them graduated from high school. While looking at the mothers' current working status, $1(14.3 \%)$ of them are working in a job whereas $6(85.7 \%)$ of them are not working. When considering marital status, $7(100 \%)$ of the mothers are married. In waiting list control group, $1(14.3 \%)$ of the mothers were below the age of $30,6(85.7 \%)$ of them were aged between $30-40$ and none of them were above the age of $40.4(28.9 \%)$ of mothers graduated from primary school, $1(19.6 \%)$ of them graduated from secondary school, 2 (34 \%) of them graduated from high school. While looking at the mothers' current working status, $3(42.9 \%)$ of them are working in a job whereas $4(57.1 \%)$ of them are not working. When considering marital status, 7 (100\%) of the mothers are married.

All detailed information of psycho-education and waiting-list control condition is presented in Table 4 and 5. According to the Chi-square tests results, no significant differences were found between groups according to age of children $(\mathrm{p}>0.05)$.

\section{Descriptive statistics of measures}

All descriptive statistics of the measures are also shown in Table 6.

Table 3. Socio-demographic characteristics of mothers in pre-assessment phase

\begin{tabular}{lll}
\hline Variables & N & \% \\
\hline Education & & \\
\hline Primary School & 28 & 28,9 \\
Secondary School & 19 & 19,6 \\
High School & 33 & 34 \\
College & 6 & 6,2 \\
University & 11 & 11,2 \\
\hline Working Status & & \\
\hline Working & 26 & 26,8 \\
Housewife & 71 & 73,2 \\
\hline Marital Status & & \\
\hline Married & 93 & 95,9 \\
Divorced & 4 & 4,1 \\
\hline Psychological Intervention & & \\
and Psychiatric Drug Use & & \\
None & 97 & 100 \\
\hline
\end{tabular}


Table 4. Socio-demographic characteristics of children in psycho-education and waiting-list control condition

\begin{tabular}{|c|c|c|c|c|}
\hline \multirow[b]{2}{*}{ Variables } & \multicolumn{2}{|c|}{ Psycho-Education Group } & \multicolumn{2}{|c|}{ Waiting-List-Control Group } \\
\hline & $\mathrm{N}$ & $\%$ & $\mathrm{~N}$ & $\%$ \\
\hline \multicolumn{5}{|l|}{ Age } \\
\hline 8 & 2 & 28,6 & 2 & 28,6 \\
\hline 9 & 3 & 42,9 & 2 & 28,6 \\
\hline 10 & 2 & 28,6 & 3 & 42,9 \\
\hline \multicolumn{5}{|l|}{ Gender } \\
\hline Girl & 4 & 57,1 & 4 & 57,1 \\
\hline Boy & 3 & 42,9 & 3 & 42,9 \\
\hline \multicolumn{5}{|l|}{ Grade } \\
\hline $3^{\text {th }}$ grade & 2 & 28,6 & 4 & 57,1 \\
\hline $4^{\text {th }}$ grade & 5 & 71,4 & 3 & 42,9 \\
\hline
\end{tabular}

\section{Preliminary Results}

Pearson correlation analysis was performed between parental attitudes, anxiety symptoms and obsessive-compulsive symptoms to assess the relationship between subclinical childhood obsessivecompulsive symptoms and parental attitudes. Marital conflict was positively correlated with total interference score in LOI-CV, $\mathrm{r}(95)=.23, \mathrm{p}<.05$ indicating that as the marital conflict increases among parents, interference of obsessive-compulsive symptoms in children also increase. Marital conflict was also positively correlated with total score in LOI-CV, $\mathrm{r}(95)=.24, \mathrm{p}<.05$ indicating that as the marital conflict increases among parents, obsessive-compulsive symptoms in children also increase. When the relationship between marital conflict and sub factors of LOI-CV were examined,

Table 5. Socio-demographic characteristics of mothers in psycho-education and waiting-list control condition results showed that marital conflict was also positively correlated with, cleanliness and tidiness, $r$ $(95)=.22, \mathrm{p}<.05$, repetition and indecision, $\mathrm{r}(95)$ $=.22, \mathrm{p}<.05$ and special words and numbers, $\mathrm{r}(95)$ $=.21, \mathrm{p}<.05$. On the other hand, there were no other significant relationships between sub scales of PARI and sub scales of LOI-CV. Marital conflict positively correlated with A-Trait anxiety symptoms, $\mathrm{r}(95)=.24, \mathrm{p}<.05$ indicating that as marital conflict increases among parents, anxiety symptoms in children also increase. Furthermore, authoritarianism positively correlated with A-Trait anxiety symptoms, $\mathrm{r}(95)=.25, \mathrm{p}<.05$ indicating that as the mother's strict and authoritarian attitudes increases, anxiety symptoms in children also increase. Additionally, A-Trait anxiety symptoms positively correlated with cleanliness and tidiness, $r$ $(95)=.28, \mathrm{p}<.01$, repetition and indecision, $\mathrm{r}(95)$ $=.34, \mathrm{p}<.01$ and special words and numbers, $\mathrm{r}$

\begin{tabular}{|c|c|c|c|c|}
\hline \multirow[b]{2}{*}{ Variables } & \multicolumn{2}{|c|}{ Psycho-Education Group } & \multicolumn{2}{|c|}{ Waiting-List-Control Group } \\
\hline & $\mathrm{N}$ & $\%$ & $\mathrm{~N}$ & $\%$ \\
\hline \multicolumn{5}{|l|}{ Age } \\
\hline$\leq 30$ & 2 & 28,6 & 1 & 14,3 \\
\hline $30-40$ & 3 & 42,9 & 6 & 85,7 \\
\hline$\geq 40$ & 2 & 28,6 & 0 & 0 \\
\hline \multicolumn{5}{|l|}{ Education } \\
\hline Primary School & 2 & 28,6 & 4 & 28,9 \\
\hline Secondary School & 1 & 14,3 & 1 & 19,6 \\
\hline High School & 4 & 57,1 & 2 & 34 \\
\hline \multicolumn{5}{|l|}{ Working Status } \\
\hline Working & 1 & 14,3 & 3 & 42,9 \\
\hline Housewife & 6 & 85,7 & 4 & 57,1 \\
\hline $\begin{array}{l}\text { Marital Status } \\
\text { Married }\end{array}$ & 7 & 100 & 7 & 100 \\
\hline
\end{tabular}


Table 6. Descriptive information of the measures

\begin{tabular}{lccc} 
Measures & M & SD & Range \\
\hline PARI & 127,84 & 15,89 & $87-172$ \\
\hline LOI-CV & 28,11 & 13,93 & $4-67$ \\
\hline A-State & 30,57 & 6,29 & $20-51$ \\
\hline A-Trait & 35,42 & 6,81 & $21-57$ \\
\hline CDI & 10,35 & 6,01 & $1-27$ \\
\hline
\end{tabular}

Note: PARI: Parental Attitude Research Instrument, LOI-CV: Leyton Obsessional Inventory Child Version, A-State and A-Trait: State-Trait Anxiety Inventory for Children, CDI: Child Depression Inventory

$(95)=.32, \mathrm{p}<.01$ and checking $\mathrm{r}(95)=.34, \mathrm{p}<.05$. In conclusion, the results indicate that there was a positive and significant correlation between total of parental negative attitudes and A-Trait anxiety symptoms, $\mathrm{r}(95)=.22, \mathrm{p}<.05$ indicating that child's anxiety symptoms increase as the mother's negative attitude increases.

\section{Main Analyses}

Chi-square Test was used to compare socio-demographic characteristics (educational status, working status and marital status) of mothers in both the groups. The results indicated that there were no significant differences $(p>.05)$ between sociodemographic characteristics of the mothers in the psycho-education group and the waiting-list-control group. In order to compare differences between psycho-education group and waiting-listcontrol group, the Mann-Whitney U test was also conducted. Results of the Mann-Whitney U test did not indicate any statistically significant differences $(\mathrm{p}>.05)$ between the psycho-education group and the waiting-list-control group according to their pre-assessments.

Table 7. Means and standard deviations of pre-test and post-test scores of mothers in psycho-education group and waiting-list-control group

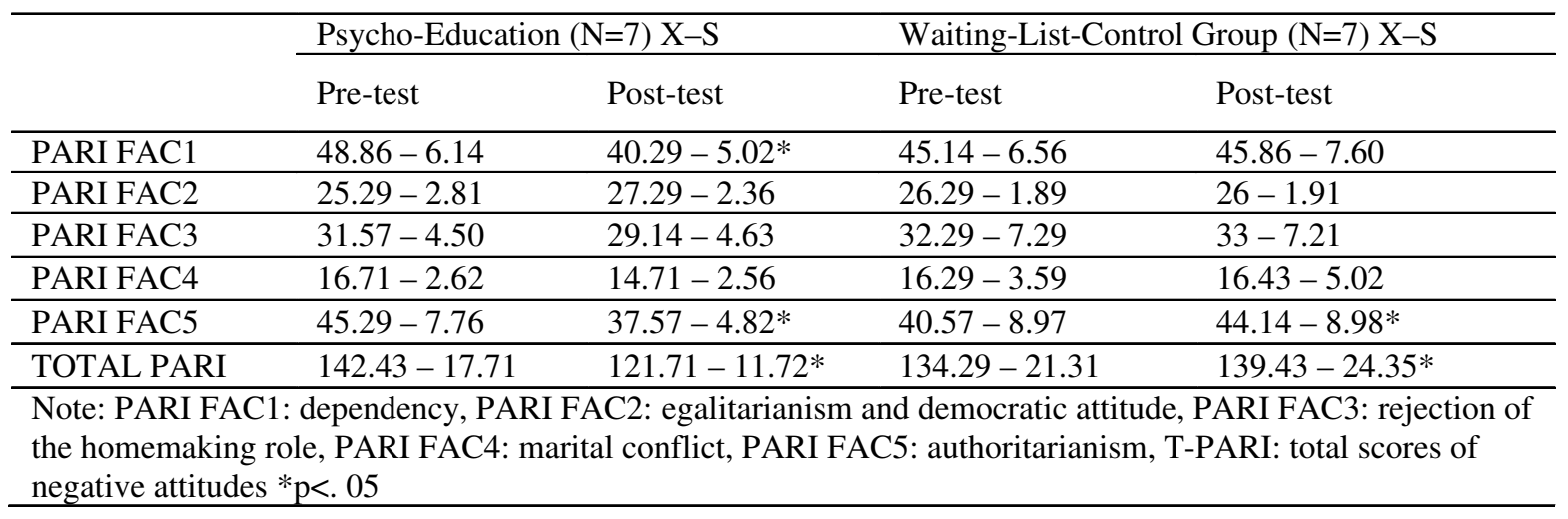


Table 8. Means and standard deviations of pre-test and post-test scores of children in psycho-education group and waiting-list-control group

\begin{tabular}{|c|c|c|c|c|}
\hline & \multicolumn{2}{|c|}{ Psycho-Education $(\mathrm{N}=7) \mathrm{X}-\mathrm{S}$} & \multicolumn{2}{|c|}{ Waiting-List-Control Group $(\mathrm{N}=7) \mathrm{X}-\mathrm{S}$} \\
\hline & Pre-test & Post-test & Pre-test & Post-test \\
\hline SYM-LOI & $16.43-1.90$ & $14.57-2.50$ & $16.50-2.02$ & $14.43-2.87$ \\
\hline INT-LOI & $31-6.24$ & $17.57-7.95 *$ & $35.43-8.01$ & $27.86-10.66$ \\
\hline T-LOI & $47.86-7.38$ & $32.14-8.31 *$ & $51.93-9.68$ & $42.29-12.67$ \\
\hline LOI FAC1 & $18.86-2.85$ & $9.14-6.23^{*}$ & $19.57-5.12$ & $15.29-6.62$ \\
\hline LOI FAC2 & $3.86-1.95$ & $3.14-.69$ & $5.43-1.39$ & $3.86-1.57 *$ \\
\hline LOI FAC3 & $2.71-2.49$ & $1.29-2.36$ & $3.43-1.90$ & $2.29-1.70 *$ \\
\hline LOI FAC4 & $5.86-1.57$ & $4-1.73^{*}$ & $7-3.21$ & $6.43-4.79$ \\
\hline A-STATE & $35-11.32$ & $26.57-7.89 *$ & $33-8.04$ & $31-5.59$ \\
\hline A-TRAIT & $42.29-9.53$ & $35.86-6.25 *$ & $40.07-8.08$ & $36-5.94$ \\
\hline
\end{tabular}

statistically significant change in OCD and anxiety symptoms of the children. There were statistically significant change in interfere score of OCD symptoms $(Z=-2.371, p=.018)$, total score of OCD symptoms $(Z=-2.366, p=.018)$, total score of cleanliness and tidiness $(Z=-2.201, p=.028)$, total score of checking $(\mathrm{Z}=-2.156, \mathrm{p}=.031)$, state anxiety symptoms $(Z=-2.366, p=.018)$ and trait anxiety symptoms $(Z=-2.207, p=.027)$. All of these scores showed a significant decrease in post assessments. There were no statistically significant changes in the total score of repetition and indecision and total score of special words and numbers. Results of the children in the waiting-list control group showed that, repetition and indecision $(Z=-2.041$, $\mathrm{p}=.041)$ and special words and numbers $(\mathrm{Z}=-$ 1.807, $\mathrm{p}=.071$ ) significantly decreased in post assessment. Other variables did not show significant change in post assessment. Means and standard deviations of pretest and posttest scores for the children are presented in Table 8 .

\section{DISCUSSION}

The first aim of this study is to investigate the relationship between parental attitudes and subclinical childhood OCD within a Turkish sample. This investigation also helped to make real the main goal of the study; to examine the effectiveness of specific 8-week psycho-education program.

Relationship between Parental Attitudes and Subclinical OCD Symptoms in Children
The first aim of this study was to investigate the relationship between maternal attitudes and child's subclinical obsessive-compulsive symptoms.

Firstly, a significant relationship was found between marital conflict and children's obsessivecompulsive symptoms and their severity. As previously investigated by March \& Mulle, this finding also revealed the marital conflict as a factor that has an effect on childhood obsessive-compulsive symptoms (13). At the same time, the relationship between marital conflict and symptom severity shows consistency with the idea that disagreement between parents over the disorder can lead more distress for the child and that affects the course and severity of OCD. Additionally, because unpredictability and distress are characteristics of obsessive-compulsive symptoms, they can lead higher tensions in family environment and cause more family conflicts.

Secondly, the current study also found a significant relationship between marital conflict and children's anxiety symptoms indicating that, an increase in marital conflict between parents can be associated with an increase in anxiety symptoms in children. This finding was supported by previous research that showed the relationship between marital conflict and childhood anxiety $(26,27)$. In the parallel with the explanation by Emery that mentioned contribution of marital conflict on childhood anxiety disorders, parents' inconsistent and instable attitudes can have an effect on the course of childhood anxiety and OCD (12). However, when considering 
a bidirectional relationship between childhood OCD and familial factors, it is also considered that living with a child who has obsessive-compulsive symptoms leads to more distress in the family environment and this can result in more marital conflict.

Contrary to expectations, the study did not found any relationship between mothers' authoritarian attitude and obsessive-compulsive symptoms of children. This result contradicts the reports of Timpano, which showed a significant relationship between obsessive-compulsive symptoms and authoritarian parenting style (28). Nevertheless, in addition to that, Timpano and colleagues also reported, authoritarian attitude can be associated with more severe cases in childhood OCD (28). Therefore, when considering the sample characteristics of this study (nonclinical school sample) and the targeted symptomatology (subclinical OCD symptoms) it can be thought that, current findings reflect and support the link between authoritarian attitude and clinical cases. More recently, Yamauchi and colleagues also stated that there is not any direct relations between maternal attitudes and child's compulsive-like behaviors (29).

In parallel with previous research, this study revealed a significant relationship between authoritarian attitude and trait anxiety symptoms $(30,31)$. According to Baumrind, authoritarian attitude is characterized by rigid parenting, strict rules, low warmth/nurturance, high demands and psychological/behavioral control (32). So the current finding also supported the meta-analytic research of McLeod et al. and the findings of Wolfradt et al. that stated an important role of excessive parental control, restricted autonomy and over involvement in child's anxiety symptoms $(33,30)$. These conflicting findings, related with the relationship between authoritarian attitudes, childhood anxiety symptoms and obsessive-compulsive symptoms, revealed the ongoing question of whether parent's authoritarian attitudes leads to childhood anxiety disorders or if it is a reaction to a child's symptomatology. Additionally, a contradiction between findings might be explained because an authoritarian attitude has a tendency to relate general anxiety symptomatology whereas it does not have any relation with subclinical obsessive-compulsive symptoma- tology.

The study findings did not indicate any relationship between dependency (overprotective attitude of mother) and either anxiety symptoms nor obsessive-compulsive symptoms. This result is somewhat unexpected and contradicts with reports from previous research which stated that parents of children with OCD have a tendency to be overprotective and less permitting for autonomy $(9,34)$. However, Alonso et al also did not find any difference in overprotective attitudes of parents between healthy and OCD groups (35). In parallel with current study, Brown \&Whiteside did not found any relation with overprotectiveness and children's anxiety (31).

\section{Effectiveness of Psycho-education Program}

\section{Quantative Results}

The second and the main aim of the present study was to examine the effectiveness of an 8-week psycho-education program on maternal attitudes and subclinical OCD symptoms of children. A significant reduction was found in negative maternal attitudes after completion of an 8-week psycho-education program. Firstly, mothers in psycho-education group experienced reductions in all their negative attitudes, while they experienced an increase in their democratic attitude. Their PARI total score, overprotective and authoritarian attitude scores decreased significantly after the 8-week psychoeducation program. These findings shows similarity to limited previous studies that indicated a reduction in negative attitudes of parents like over criticism, overprotectiveness, over involvement, whilst showing an increase in positive behaviors (17,36, ,37). Furthermore, in the current study, mothers also supported these findings with their own reports during the sessions. During psycho-education they also observed their own negative attitudes in the dimensions of nagging, yelling, persuading, hostile looks, snide comments and laughing/joking at a child using a negative attitude monitoring form and tried to replace them with positive alternative behaviors. At the beginning, they mostly reported nagging, yelling and hostile look behaviors and towards the end of the program, they began to use 
their own coping strategies rather than their negative attitudes. As discussed in case reports in the next section, some of the mothers also reported a reduction in their strictness about rules and punishments.

Considering other results, even though reductions were also observed in the mother's rejection attitude towards to homemaking role and marital conflict, these changes were not significant. The homemaking role is highly related with responsibility that attributed to mothers by society in Turkey. Therefore, the content of the psycho-education may be insufficient to address that issue. A relationship between marital conflict and childhood anxieties was identified in this study and is also supported by the results of previous studies' $(26,27)$. It is possible to speculate that, significant changes in marital conflict were not obtained from the participants of psycho-education program because the study had a restricted sample containing only mothers. It is possible that, mothers explained some informations about the nature of symptoms or functional attitudes to fathers, but it would not be sufficient to produce significant changes regarding the behavior of fathers and conflict between spouses.

The study findings indicate that the psycho-education group showed a significant decrease in their negative attitudes while waiting-list control group did not show any positive changes. With this finding, efficacy of psycho-education on negative attitudes of mothers was evaluated. Moreover, the total scores of negative attitudes and authoritarian attitude scores of mothers in the waiting-list control group showed an increase during the 8 week period. It was previously evaluated that as the familial factors has an effect on childhood OCD; symptoms also affect family attitudes and functioning (2). So the findings of waiting-list control group may suggest that, attitudes of mothers became more negative against a compelling course of symptoms in time. It can be also speculated that, because mothers in the waiting-list control group did not have any knowledge about symptoms, they were unable to understand their child's behaviors and their blame and strictness increases over time. This prediction is supported by previous research that indicated caregivers of OCD patients experi- enced more anger, frustration, blame, family crisis etc. over time when compared to intervention and control groups (38).

Depending on the main aim of the current study, the results indicated significant reductions in subclinical OCD symptoms and anxiety symptoms of children who's mothers had completed the 8-week psycho-education program. Firstly, these children showed a significant decrease in interfere and total score of LOI, cleanliness/tidiness, and in checking after completion of the program. These findings are consistent with a previous study in which specific parenting practices included in addition to other familiar techniques and reduction in OCD symptoms was obtained (39). Mothers in the psychoeducation group also supported these findings with their own reports during the sessions. After completion of the psycho-education program two mothers reported a decrease in their children's cleaning compulsion whereas three of them reported a decrease in the checking compulsion of their children. Even though this study did not contain any direct interventions for children, findings also showed similarity with previous studies that compared child intervention and child intervention plus family involvement in some way $(40,41,42)$. In all of these previous studies, family interventions caused more positive treatment outcomes. Furthermore, as in recent studies, this finding also supported the effect of parent only interventions on childhood OCD $(14,39)$. Secondly children also showed a significant decrease in state and trait anxiety symptoms. This was an expected result in the light of previous research that highlighted a significant relationship between parental attitude and level of childhood anxiety $(30,31)$. In this way, current research demonstrates that a positive change in maternal attitudes leads to a decrease in a child's anxiety.

Although there were reduction in the symptom score of LOI, repetition/indecision and special words/numbers, these changes were not significant. Taken together, findings about symptom, interfere and total scores may suggest that the positive changes in maternal attitudes obtained through psycho-education just had an effect on symptom severity rather than symptom presence. It will be possible to observe changes in the symptom pre- 
sence through a long-term follow-up plan. In other respects, special words and numbers can be explained with counting compulsion, which means counting certain number or repeating words while doing something. Repetition also explains the repeated actions. For in both compulsion types, they can manifest themselves as mental acts rather than behaviors. So it can be speculated that, children can hide their related symptoms more easily therefore it is more difficult to intervene in these symptoms.

Significant reductions were also observed in the results from the psycho-education group compared to the waiting-list-control group regarding children's subclinical OCD and anxiety symptoms. These findings indicate that the children in the psycho-education group showed more significant decrease in their subclinical OCD and anxiety symptoms as compared to waiting-list control group. With the exception of the repetition/indecision and special words/numbers, children in waiting-list control group did not produce significant reduction in other factors of LOI and in state/trait anxiety symptoms. The unexpected result associated with the reduction in repetition/indecision and special words/numbers can be related to the nature of subclinical OCD. In subclinical OCD, obsessive and compulsive symptoms mostly exist in variable nature and there is no severe functional impairments in the individual's life. It is also known that the relationship between subclinical OCD and clinical OCD is still controversial. Previous study findings, also indicated in follow ups, show that some participants with subclinical OCD symptoms moved to OCD, some of them remained with their subclinical OCD symptoms and some of them did not show any OCD symptoms going forward without any interventions. As in this study, natural reduction also observed in a previous study that examined the effectiveness of an early intervention program? for subclinical OCD (43). It is still debatable if this current finding represents the waxing and waning course of subclinical OCD or if these symptoms really remit without any intervention.

\section{Qualitative Results}

Although findings about the presence of the child- ren's symptoms were obtained through the assessment process, mothers also reported about these symptoms in more detail during the psycho-education process. Therefore it was decided that it would be more meaningful to study to discuss all of these reports, separately. Mothers were also asked to observe and monitor the symptomatology of their children using monitoring forms during the process but detail information about symptoms could not be obtained from these monitoring forms. If was found that mothers tended to conceal their children's symptoms on the written forms. However, they felt able to talk about these symptoms during face-to-face communications. It is possible that, although issues regarding confidentiality were explained at the beginning of process, mothers still had concerns about the publication of their personal information in the dissertation study. Therefore all of the information about each case presented in the following section is purely based on the notes taken by the researcher during the psycho-education sessions.

In general, it is observed that most of the symptoms either increase or decrease in severity or disappear with time rather being permanent. The severity of the symptoms varied from case to case but in most cases symptoms did not cause any impairments to the child's life.

\section{Strengths and Limitations of the Study and Suggestions for Future Research}

One of the strengths of this study is the inclusion of children aged 8 to 10 years as this age group is recognized in the literature as the onset of childhood OCD. As there is a consensus among the research community regarding this onset age, adults who receive an OCD diagnosis in their adulthood, also had OCD symptoms in their childhood, this current study can facilitate the follow up development and maintenance of OCD symptoms in children $(44,45,46)$.

Another strength of the study is the examination of a subclinical sample. Even though relationship between subclinical OCD and clinical OCD is still controversial, some previous studies have demonstrated the possibility that subclinical OCD can be 
precursor to $\operatorname{OCD}(2,5,47)$. In this aspect, it can be considered that this study also showed a preventive effort in a nonclinical sample.

In general, many parents find it difficult to attend therapy sessions because of their intensive work hours, household responsibilities or bias about parent sessions. However this study demonstrated that full attendance could be achieved within 8 weeks. It can often be difficult to arrange and coordinate session schedules and conduct sessions within a group environment. Despite this, the study conducted a group psycho-education program with the mothers rather than individual sessions.

Unlike some of the previous studies, this study had a comparison group and this facilitated the ability to determine which specific components of the psycho-education led to a change in maternal attitudes $(9,40,48)$. Furthermore, changes in the process were examined by looking at changes in the negative attitudes of mothers and OCD symptomatology. Furthermore the the positive effects of psychoeducation was observed in psycho-education group.

There is also a need to address a number of limitations and future directions. Firstly, in the current study, the measure that examines the maternal attitudes was chosen from a limited number of Turkish adaptation studies. Although PARI is one of the best measures available to assess maternal attitudes, it is not focused on the parental attitudes (especially expressed emotion) related to childhood OCD. For example, Peris and colleagues developed The Parental Attitudes and Behavior Scale (PABS), which is an OCD specific parental attitudes scale and demonstrated validity and reliability of the scale (49). Further research should work on using an adaption of an OCD related parental attitude tool such as PABS. Using an OCD specific parental attitudes scale can help researchers to observe any direct relationship between childhood OCD and parental attitudes.

As the study sample comprised of nonclinical subjects, it should be replicated with a clinical OCD sample in order to more clearly observe the relationship between parental attitudes and obsessivecompulsive symptoms. The generalizability of the this study was also limited because of the sample size. Therefore, future studies will need to enlarge the sample size.

Some of the mother participants also reported OCD like symptoms in themselves or in firstdegree relatives. However, this study did not examine parental psychopathology or its effect on parenting attitudes and child symptoms. This limitation means that the answers to the potential question of whether parental psychopathology is responsible for parenting style or child symptomatology is still debatable. In considering the genetic vulnerability of OCD and the association between parental psychopathology and parenting, future research should also examine psychopathology of the parents to increase the efficacy of the studies.

This study also focused on the parents' self-reporting of their parental attitudes. Considering the possible discrepancies between children and parents' self-reports in relation to parental attitudes, future studies should attach importance to child's selfreports too. Additionally only mothers were involved in the study. This also limits the generalizability of the current results to entire family attitudes. According to the current findings, marital conflict has a relation with childhood OCD and psycho-education cannot elicit significant change in this dimension. This finding therefore demonstrates the importance of a father's involvement in the process. Therefore, future research could involve all family members in the process.

\section{CONCLUSION}

The findings of the current study are consistent with previous evidence suggesting a relationship between negative parental attitudes (marital conflict) and subclinical childhood OCD symptoms. Furthermore, effectiveness of a manualized psycho-education program about maternal attitudes towards childhood OCD was investigated for the first time in a Turkish sample. Efficacy of psychoeducation on the negative attitudes of mothers and on children's subclinical OCD and anxiety symptoms was proved.

In the light of the current findings several potential 
The effect of psycho-education about maternal attitudes on childhood obsessive compulsive disorder symptoms

clinical implications emerge. Current findings add to growing sense that maternal attitudes should be considered as part of the treatment of childhood OCD. The findings support the importance of obtaining more comprehensive information about family attitudes during clinical assessments of childhood OCD. Although there is a need to complete longitudinal follow up on both the mothers' attitudes and their children's symptoms in order to assess long-term effectiveness of the psycho-educa- tion program, current findings provide crucial information to clinicians about the need to work with parents in treatment of childhood OCD.

Correspondence address: Assis. Prof. Oya Mortan Sevi, Bahcesehir University, Faculty of Economics, Administrative and Social Sciences, Department of Psychology, Istanbul, Turkey oya.mortansevi@eas.bau.edu.tr

\section{REFERENCES}

1. American Psychiatric Association. Diagnostic and Statistical Manual of Mental Disorders, 4th Edition (DSM-4 TR).Washington DC, American Psychiatric Pub, 2000, pp. 417 423.

2. Black DW, Gaffney GR. Subclinical obsessive-compulsive disorder in children and adolescents: additional results from a "high-risk" study. CNS Spectr 2008; 13:54-61.

3. Brown FC, Katz LJ, Roth RM, Beers SR. The relationship of self-reported subclinical obsessive-compulsive symptoms and impulsivity among adults with AD/HD. Psychiatry Res 2014; 216:131-136

4. Leonard HL, Swedo SE, Lenane MC, Rettew DC, Hamburger SD, Bartko JJ, Rapoport JL. A 2-to 7-year followup study of 54 obsessive-compulsive children and adolescents. Arch Gen Psychiatry 1993;50:429-439.

5. Valleni-Basile LA, Garrison CZ, Waller JL, Addy CL, McKeown RE, Jackson KL, Cuffe SP. Incidence of obsessivecompulsive disorder in a community sample of young adolescents. J Am Acad Child Adolesc Psychiatry 1996;35:898-906.

6. Farrell LJ, Barrett PM. The function of the family in childhood obsessive-compulsive disorder: family interactions and accommodation. Handbook of child and adolescent obsessivecompulsive disorder. Edited by Storch EA, Geffken GR, Murpy TK. New Jersey, Lawrence Erlbaum Associates, 2007, pp. 313332.

7. Waters TL, Barrett PM. The role of the family in childhood obsessive-compulsive disorder. Clin Child Fam Psychol Rev 2000; 3:173-184

8. March JS. Cognitive-behavioral psychotherapy for children and adolescents with OCD: a review and recommendations for treatment. J Am Acad Child Adolesc Psychiatry 1995;34:7-18.

9. Barrett P, Shortt A, Healy L. Do parent and child behaviours differentiate families whose children have obsessive-compulsive disorder from other clinic and non-clinic families?. J Child Psychol Psychiatry 2002;43:597-607.

10. Hibbs ED, Hamburger SD, Lenane M, Rapoport JL, Kruesi MJ, Keysor CS, Goldstein MJ. Determinants of expressed emotion in families of disturbed and normal children. J Child Psychol Psychiatry 1991; 32:757-770.

11. Amir N, Freshman M, Foa EB. Family distress and involvement in relatives of obsessive-compulsive disorder patients. $\mathbf{J}$ Anxiety Disord 2000;14:209-217.
12. Emery RE. Interparental conflict and the children of discord and divorce. Psychol Bull 1982;92:310.

13. March JS, Mulle K. OCD in children and adolescents: A cognitive-behavioral treatment manual. New York, Guilford Press, 1998, pp. 188.

14. Lebowitz, E.R. Parent-based treatment for childhood and adolescent OCD. J Obsessive Compuls Relat Disord 2013;2: 425-431.

15. Rosa-Alcázar AI, Iniesta-Sepúlveda M, Storch EA, RosaAlcázar Á, Parada-Navas JL, Rodríguez JO. A preliminary study of cognitive-behavioral family-based treatment versus parent training for young children with obsessive-compulsive disorder. J Affect Disord 2017; 208:265-271.

16. Dobson D, Dobson KS. Evidence-based practice of cognitive-behavioral therapy. New York, Guilford Publications, 2018, pp. 78.

17. Piacentini J, Bergman RL, Chang S, Langley A, Peris T, Wood JJ, McCracken J. Controlled comparison of family cognitive behavioral therapy and psychoeducation/relaxation training for child obsessive-compulsive disorder. J Am Acad Child Adolesc Psychiatry 2011; 50:1149-1161.

18. Steketee G, Noppen BV. Family approaches to treatment for obsessive compulsive disorder. J Fam Psychother 2004;14:55-71.

19.Kircanski K, Peris TS, Piacentini JC. Cognitive-behavioral therapy for obsessive-compulsive disorder in children and adolescents. Child Adolesc Psychiatr Clin 2011;20:239-254.

20. LeCompte G, LeCompte A, Özer S. Üç sosyoekonomik düzeyde Ankaralı annelerin çocuk yetiştirme tutumları: Bir ölçek uyarlaması. Psikol Derg 1978;1:5-9.

21. Kucuk S. The validity of the Turkish form of the PARI subscales. U.B. doctorate Thesis.1987.

22. Palulu N, Erol N. The prevalance of obsessive compulsive disorder in primary and secondary school children: A norm study. Turk J Child Adolesc Ment Health 1999; 6:89-98.

23. Özusta Ş. Çocuklar için durumluk-sürekli kaygı envanterinin uyarlama, geçerlik ve güvenirlik çalışması. Türk Psikol Derg 1995;10:32-44.

24. Kovacs M. Rating scales to assess depression in school-aged children. Int J Child Adolesc Psychiatr 1981;46:305-315.

25. Oy B. Cocuklar icin Depresyon Olcegi gecerlik ve guvenirlik calismasi. Turk Psikiyatr Derg 1991; 2:137-140. 
26. Jekielek SM. Parental conflict, marital disruption and children's emotional well-being. Soc Forces 1998;76:905-936.

27. Spence SH, Najman JM, Bor W, O'callaghan MJ, Williams GM. Maternal anxiety and depression, poverty and marital relationship factors during early childhood as predictors of anxiety and depressive symptoms in adolescence. J Child Psychol Psychiatry 2002;43:457-469.

28. Timpano KR, Keough ME, Mahaffey B, Schmidt NB, Abramowitz J. Parenting and obsessive compulsive symptoms: Implications of authoritarian parenting. Int J Cogn Ther 2010; 24:151-164.

29. Yamauchi H, Ogura M, Mori Y, Ito H, Honjo S. The Effects of Maternal Rearing Attitudes and Depression on CompulsiveLike Behavior in Children: The Mediating Role of Children's Emotional Traits. Psychol 2016; 7:133.

30. Wolfradt U, Hempel S, Miles JN. Perceived parenting styles, depersonalisation, anxiety and coping behaviour in adolescents. Pers Individ Dif 2003;34:521-532.

31. Brown AM, Whiteside SP. Relations among perceived parental rearing behaviors, attachment style, and worry in anxious children. J Anxiety Disord 2008;22:263-272.

32. Baumrind D. Patterns of parental authority and adolescent autonomy. New Dir Child Adolesc Dev 2005;108:61-69.

33. McLeod BD, Wood JJ, Weisz JR. Examining the association between parenting and childhood anxiety: A meta-analysis. Clin Psychol Rev 2007; 27:155-172.

34. Haciomeroglu B, Karanci AN. Perceived parental rearing behaviours, responsibility attitudes and life events as predictors of obsessive compulsive symptomatology: Test of a cognitive model. Behav Cogn Psychother 2014; 42:641-652.

35. Alonso P, Menchón JM, Mataix-Cols D, Pifarré J, Urretavizcaya M, Crespo JM, Jiménez S, Vallejo G, Vallejo J. Perceived parental rearing style in obsessive-compulsive disorder: relation to symptom dimensions. Psychiatry Res 2004; $127: 267-278$.

36. Peris TS, Bergman RL, Langley A, Chang S, Mccracken JT, Piacentini J. Correlates of accommodation of pediatric obsessive-compulsive disorder: parent, child, and family characteristics. J Am Acad Child Adolesc Psychiatry 2008;47:1173-1181.

37. Schlup B, Farrell L, Barrett P. Mother-child interactions and childhood OCD: Effects of CBT on mother and child observed behaviors. Child Fam Behav Ther 2011;33:322-336.

38. Black DW, Gaffney G, Schlosser S, Gabel J. The impact of obsessive-compulsive disorder on the family: preliminary findings. J Nerv Ment Dis 1998;186:440-442.

39. Ginsburg GS, Burstein M, Becker KD, Drake KL. Treatment of obsessive compulsive disorder in young children: an intervention model and case series. Child Fam Behav Ther 2011;33:97122.

40. Waters TL, Barrett PM, March JS. Cognitive-behavioral family treatment of childhood obsessive-compulsive disorder: preliminary findings. Am J Psychother 2001;55:372-387.

41. Peris TS, Sugar CA, Bergman RL, Chang S, Langley A, Piacentini J. Family factors predict treatment outcome for pediatric obsessive-compulsive disorder. J Consult Clin Psychol
2012;80:255.

42. Thompson-Hollands J, Edson A, Tompson MC, Comer JS. Family involvement in the psychological treatment of obsessivecompulsive disorder: A meta-analysis. J Fam Psychol. 2014; 28:287.

43. Zucker BG. Early intervention for subclinical obsessivecompulsive disorder. University of California, Doctoral dissertation. 2004.

44. Karno M, Golding JM, Sorenson SB, Burnam MA. The epidemiology of obsessive-compulsive disorder in five US communities. Arch Gen Psychiatry 1988;45:1094-1099.

45. do Rosario-Campos MC, Leckman JF, Mercadante MT, Shavitt RG, Prado HD, Sada P, Zamignani D, Miguel EC. Adults with early-onset obsessive-compulsive disorder. Am J Psychiatry 2001;158:1899-1903.

46. Geller DA. Obsessive-compulsive and spectrum disorders in children and adolescents. Psychiatr Clin North Am 2006; 29:353-370.

47. Black DW, Stumpf A, McCormick B, Allen J, Blum N, Noyes R. A blind re-analysis of the Iowa family study of obsessive-compulsive disorder. Psychiatr Res 2013; 209:202-206.

48. Farrell LJ, Schlup B, Boschen MJ. Cognitive-behavioral treatment of childhood obsessive-compulsive disorder in community-based clinical practice: Clinical significance and benchmarking against efficacy. Behav Res Ther 2010;48:409-417.

49. Peris TS, Benazon N, Langley A, Roblek T, Piacentini J. Parental attitudes, beliefs, and responses to childhood obsessive compulsive disorder: the parental attitudes and behaviors scale. Child Fam Behav Ther 2008;30:199-214. 